\title{
VISUAL AIDS IN LANGUAGE EDUCATION
}

\author{
Marioara PATEŞAN*, Alina BALAGIU**, Camelia ALIBEC** \\ * "Nicolae Bălcescu" Land Forces Academy, Sibiu, Romania \\ ** "Mircea cel Bătrân" Naval Academy, Constanţa, Romania \\ mpatesan@yahoo.com, alinabalagiu@yahoo.com,cami_alibec@yahoo.com
}

\begin{abstract}
Visual aids are powerful tools that can be used to assist the teachers in teaching a foreign language. They can be used to display complex information clearly and introduce variety into the activities in class. The benefits in using visuals in teaching are huge, ranging from grabbing and maintaining attention to motivating students to engage with the lecture's particular topic and helping them to retain information. Specialists as well as teachers agree on the important role of visuals that can significantly enhance the learning of students that belong to a generation familiar with the visual interface of multimedia and internet technologies. The present paper examines some of the theoretical and practical aspects of the use of visual aids in the English language classroom.
\end{abstract}

Keywords: visual materials, teaching and learning process, language classroom, communication

\section{Introduction}

The students like using technology all the time, if possible. Keeping them motivated and actively participative in class has become a challenging task. Using multimedia audio-visual aids in the English classroom has become a must if we want to increase the students' interest, knowledge and proficiency in the English language. Modern technologies offer possibilities to integrate the visual aids into the language classrooms.

The older generations remember the way they were taught foreign languages: from printed books, pictures, drawings, very few didactic films or realia mainly to help students associate words for common objects and the objects themselves. It was good to teach concrete vocabulary. But when it comes to more complex or subtle one then there was a problem. Nowadays the teachers have at their disposal so many modern ways to teach a foreign language, to bring the real world into the classroom. DOI: $10.1515 / \mathrm{kbo}-2018-0115$

(C) 2015. This work is licensed under the Creative Commons Attribution-NonCommercial-NoDerivatives 3.0 License.
Printed texts alone are no longer attractive for the 'thumb generation'. By using various forms of communication into class like illustrations, diagrams, drama, charts, mime, models, overhead projectors or multimedia presentations we enable students to understand and learn. The use of visuals in the classroom makes the students more interested, more attentive to the topic presented as they are provided with a more meaningful context. Thus, they become more participative and communicative. Teachers at their turn have learnt how to be more creative by using media in class to make the teaching and learning process become interesting and enjoyable. Nowadays teachers need- more than academic expertise. They should be able to use the teaching strategies and aids that fit the students' expectations as well. The teachers should support the communicative interaction in class and both the modern technological means and didactical software can be of great help. 
In developing skills like speaking or writing, students can use a wide range of forms such as: tables, graphs, charts, diagrams, photographs, you tube films to convey spoken or written messages. By oral presentations on given topics they enhance the speaking competence while the organization of ideas in a written form or making up dialogues for example, help them enhance writing.

By simply viewing a PowerPoint presentation not only have the students the opportunity to acquire information visually transmitted by the teacher or fellow students but also they become more interested and involved in the activities in class. The language acquisition can be achieved by using meaningful visuals that are more helpful in the students' memorization of new vocabulary or structures. Along the academic semesters the visual materials used help the teachers show the students the culture of the foreign language, the customs and the body language so meaningful during the real-life communication, the military traditions or logistics specific to English speaking countries or NATO partners.

\section{Theoretical background}

Contemporary culture has become increasingly dependent on the visual mainly for its capacity to send messages, photos etc. in an instant all over the world. Due to the modern technologies such as computers and interactive whiteboards, teachers have increased possibilities to integrate visual materials into a lesson. No matter which teaching method you choose to use, visual aids will make a difference. Students no longer accept dull, boring presentations when the teacher is speaking and the students sit quietly and take notes. They want active participation in the teaching process. The teacher becomes an actor and the students are invited to participate in the play staged in class. Starting with simple gestures and pantomimes to pictures, photographs and slides all are used "to make the activities more motivating and meaningful for the students". Thomas, M. and Keinders, H. [1] as well as Mannan stress the fact that the use of visuals 'help the teacher to clarify, establish, correlate and coordinate accurate concepts, interpretations and appreciations, and enable him to make learning more concrete, effective, interesting, inspirational, meaningful and vivid' [2] Moriarty finds an explanation claiming that it is specific to human beings to develop their visual language skills before the verbal language development" [3] offering a possible explanation for "the need of pictorial information rather than textual among young students "as he explained. Paivio [4], on the other hand, developed his own theory based on the idea that "cognitive growth is stimulated by the balance between verbal and visual experiences in the early stages of learning while Arif and Hashim's own research proved that "pictures gained better attention than words", and that "pictures became the main clue in interpreting the meaning of the words". [5] Experts as teachers alike agree that visuals help arising the readers' interest, curiosity and motivation.

Most of the language teachers seem to agree that the use of visuals can enhance language teaching and that the real world brought into the classroom can "make learning more meaningful and more exciting" [6]. Bamford advises the teachers to take into consideration the fact that visual literacy is the best way "to obtain information, construct knowledge and build successful educational outcomes". She asserts that this is "due to the increase of the number of images in the world and defines visual literacy as "the ability to construct meaning from visual images" even if we agree or not "visual images are becoming the predominant form of communication across a range of learning and teaching resources." [7]

Visual materials can make a lesson more attractive and the experts agree that they help both the teachers and students in the teaching-learning process. Thus, Carney 
and Levin [8] demonstrated that the "visual materials make a difference" in the process of teaching and learning, as they serve as "metal scaffolds for the students and help teachers to correlate and coordinate accurate concepts" making the learning more attractive. [9] Moreover, pictures and videos can serve as a "connection between the mother tongue and English, so direct translations are not needed" and neither "the excessive explanations and translations" [10] All the teaching methods used in class over the years starting with the direct approach, the audio-lingual method or the comprehension-based approach made use of visuals or tape recordings to avoid the use of mother tongue in class. The Communicative Language Teaching stressed the need for real life objects or texts to give authenticity to the communicative situation as: "Non native speakers (both inside the classroom and outside the classroom) make use of the here and now objects in the immediate environments" [11]

\section{The use of visuals in the foreign language acquisition}

Since most people are visual learners, it's important to go beyond "spoken words" when educating students. Students are also more likely to learn material is they're exposed to it in a variety of ways.

As Kang claims," they are designed to help the learner, bringing the prior knowledge to a conscious level in the form of an organizational structure. They help enhancing comprehension and learning, as well as eliciting, explaining and communicating information."In his opinion the advantages provided by visual organizers are as follows:

- they allow users to develop a holistic understanding that words cannot convey.

- they provide users with tools to make thought and organization processes visible.

- they clarify complex concepts into a simple, meaningful display.
- they assist users in processing and restructuring ideas and information and - they promote recall and retention of learning through synthesis and analysis.

He considers that these advantages are "especially important in Second Language Instruction because the language deficiencies of the learners are compensated by the visuals". [12]

The foreign language teachers consider the importance of learning the language in an environment as close as possible to the native one. Having at their disposal softwares with native voices and situations from real life help the teachers create a proper, real to life scenario which can make students hear and see the natives in their native places. Geeraerts, considers that the "linguistic meaning is based on usage and experience", and therefore students should be place in an environment that "trigger their experiences and let them use the language for real purposes" as often as possible. [13]

Moreover Gass is sure that "second language acquisition is shaped by the input one receives' [14] while Fotos herself, considers that the "input the students receive in the classroom can be manipulated in order to make it easier to understand, fitting their needs and level". She goes further in arguing that "teachers have been doing it over the years, with different strategies such as simplifying the grammar activities or physically highlighting the important points of a particular topic (grammar structures or vocabulary) in the presentations or in the prints that they hand to them". [15] Nation and Newton also believe that students are capable of understanding a foreign language as the visuals used will "provide conceptual scaffolding, through cultural context or other clues, and it helps with the natural associations of images and words". [16]

Lakoff and Johnson, are the specialists who coined a new term called the "Experiential Realism" , based on the assumption that there is a reality "out there", and that the 
purpose of "our perceptual and cognitive mechanisms is to provide a representations of this reality" by using multimedia visual aids in the English language class (cited in Evans and Green, 2006) [17] In their studies they found out that more than "two dozen different image schemas and several image schema transformations" appear regularly in people's "everyday thinking, reasoning and imagination”. [18]

\section{Using visuals in the language Classroom}

The teachers should integrate the mediabased materials if they want students to learn effectively and as Brinton pointed out "use media materials when variety is called for, when they expedite your teaching task and serve as a source input, and/or when they help you to individualize instruction and appeal to the variety of cognitive styles in your classroom. But above all, use media to involve students more integrally in the learning process and to facilitate language learning by making it a more authentic, meaningful process." [19]

Levin and Mayer explain the beneficial effects of the visuals and the reasons why pictures facilitate comprehension and learning are. They proposed some principles called the seven " $\mathrm{C}$ ". According to their words pictures make the text more: concentrated, compact/concise, coherent, comprehensible, correspondent and codable. [20]

\subsection{Visuals used in Power point presentation}

Teachers have noticed that students prefer "coloured visuals, pictures that contain a story, that can be related to previous experiences and that can be 'associated with places, objects, persons, events or animals of which they are familiar". CanningWilson Nowadays, teachers can use different resources to support their explanations turning them into attractive information. We have noticed that well prepared slides increased students' motivation, got their attention and brought clarification of the situations presented or of the information communicated. We also can involve students in academic discussions based on academic content by:

- responding to factual and inferential questions;

- demonstrating comprehension of inferential or abstract questions that are based on academic content;

- analyzing and evaluating visual texts and multimedia texts that use visuals;

- providing data or clarifying information on given topics;

- supporting a conclusion or finding by stating facts or logical reasons. [21]

For example, in a lesson about leadership you can start with a simple question:

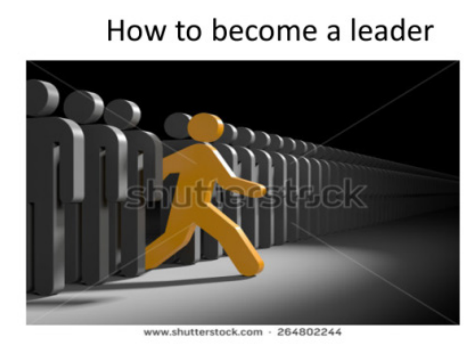

Then you can use the next slide to ask their opinions on how difficult it is to be a genuine leader and what one can do to make the impossible possible!

Is it easy?
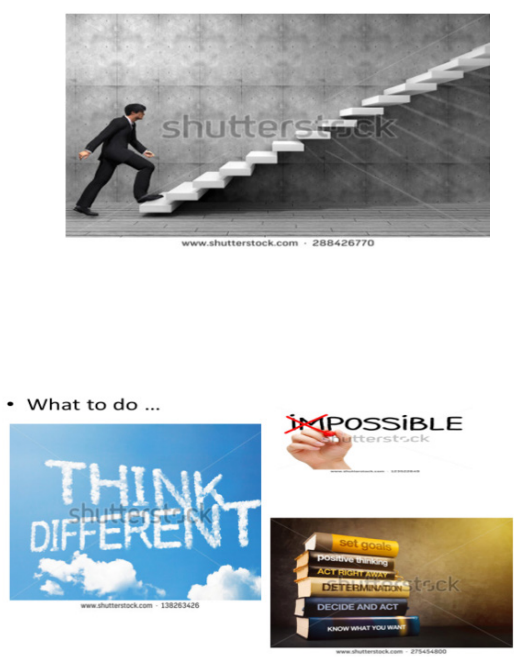
By showing these two slides you tell them what their subordinates expect them to be if they want their respect for example.

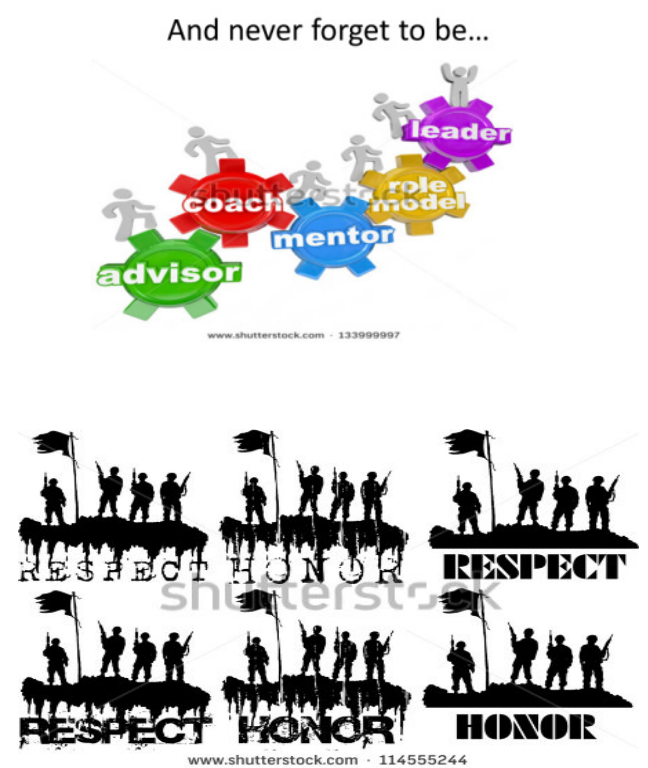

In stressing a leader's skills, the students can be challenged to give examples of situations they were directly involved in or heard about in one of/ these abilities were of utmost importance.

Good leader's skills

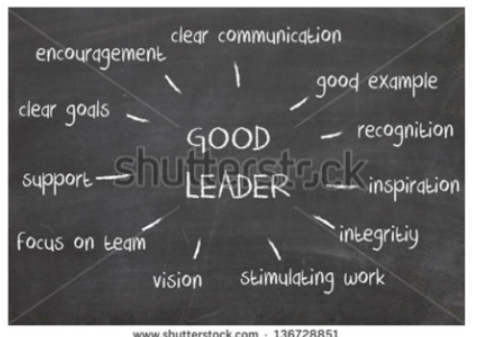

You can also introduce funny provocative slides related to the information you want to stress...

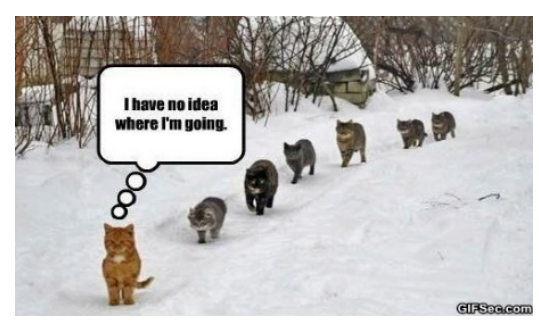

or draw comparisons to make them understand your point:

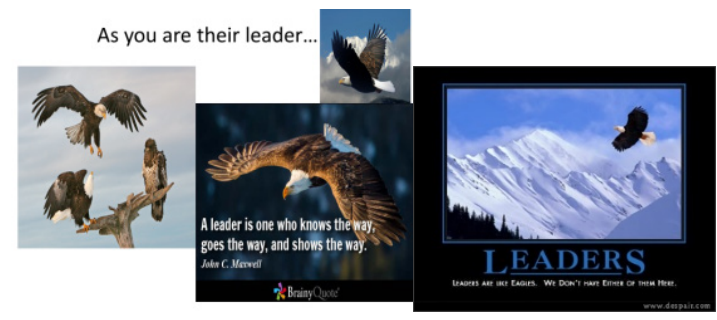

\section{Conclusions}

Visual aids as an additional tool in the teaching-learning process, when appropriately chosen and designed are important as students are stimulated, motivated and focused on the activities in class, thus enhancing learning. Integration of technology into classroom help the teachers explain concepts and ideas in a meaningful close- to -real- life way. The students' acquisition and learning improve, the classes become more attractive and interactive, in short, visuals make the materials to be taught clearer and the learning more accessible.

The visual aids help English-language learners build their vocabulary, speaking, listening as well as the writing skills, making them more creative and develop their deep thinking. Effective use of visuals can be beneficial and can lead to permanent learning as well as help the content delivery.

\section{References}

[1] Thomas, M. and Keinders, H. (Ed.), Task-based language learning and teaching with technology. London; New York: Continuum, 2010, pp. 25-26.

[2] Mannan, A., Modern Education: Audio-Visual Aids. New Delhi: Anmol Publications, 2005, pp. 14-16.

[3] Moriarty, S.E., 'Visual Communication as a primary system' Journal of Visual Literacy, Vol. 4, no. 2, 1994, pp. 11-21. 
[4] Paivio, A. and Clark, J.M., Usage of Multimedia Visual Aids in the English Language Classroom 'in Dual-Coding Theory and Education' Educational Psychology Review, Vol. 3, no. 3, 1991, p. 52

[5] Arif, M., and Hashim, F., Young Learner s Second Language Visual Literacy Practices. Oxford: Inter-Disciplinary Press, 2009.

[6] Brinton, D.M., 'The use of Media in Language Teaching', in Celce-Murcia, M. (ed.) Teaching English as a second or foreign language (3rd ed., pp. 459-475). Boston: Heinle and Heinle, 2001.

[7] Bamford. Anne: The visual literacy white paper https://www.aperture.org/wpcontent/uploads/2013/05/visual-literacy-wp.pdf, retrieved March 8, 2018

[8] Carney, R.N and Levin, J.R., 'Pictorical Illustrations still Improve students' Learning from Text' Educational Psychology Review, Vol. 14, no. 1, March, 2002.

[9] Mannan, A., Modern Education: Audio-Visual Aids. New Delhi: Anmol Publications, 2005, p. 108.

[10] Brinton, D.M., 'The use of Media in Language Teaching', in Celce-Murcia, M. (ed.) Teaching English as a second or foreign language (3rd ed., pp. 459-475). Boston: Heinle and Heinle, 2001.

[11] Idem, p. 459.

[12] Kang, S. 'Using Visual Organizers to enhance EFL instruction' ELT Journal, vol. 58, no. 1, January, 2004.

[13] Geeraerts, D., 'A rough guide to Cognitive Linguistics' in Geeraert (ed.) Cognitive Linguistics: Basic Readings, (pp 1-28). Berlin: Mouton de Gruyter, 2006.

[14] in Fotos, S., Cognitive approaches to grammar instruction. In M. Celce-Murcia (Ed.), Teaching English as a second language (3rd ed., pp. 267-283). Boston: Heinle \& Heinle, 2001.

[15] Fotos, S., Cognitive approaches to grammar instruction. In M. Celce-Murcia (Ed.), Teaching English as a second language (3rd ed., pp. 267-283). Boston: Heinle \& Heinle, 2001.

[16] Nation I.S.P. and Newton, Jonathan, Teaching ESL/EFL Listening and Speaking Routledge, 2009, p. 31.

[17] Lakoff and Johnson in Evans, V. and Green, M., Cognitive Linguistics: An Introduction. Oxford University Press. Usage of Multimedia Visual Aids in the English Language Classroom, 2006, p. 50.

[18] Gibbs, R.W. Jr. and Colston, H.L., 'Image Schema: The cognitive psychological reality of image schemas and their transformations' in Geeraert (ed.) Cognitive Linguistics: Basic Readings, (pp. 239-268). Berlin: Mouton de Gruyter, 2006.

[19] Brinton, D.M., 'The use of Media in Language Teaching', in Celce-Murcia, M. (ed.) Teaching English as a second or foreign language (3rd ed). Boston: Heinle and Heinle. (p. 130), 2001.

[20] Levin, J.R. and Mayer, R.E., 'Understanding illustrations in text', in Brinton, B.K., Woodward, A. and Brinkley, M. (eds.). Learning from textbooks, Erlbaum, 1993, pp 95-113.

[21] Canning-Wilson, C., 'Visuals and Language Learning: Is there a connection?' The Weekly Column, article 48, February, 2001, retrieved from http://www.eltnewsletter.com/back/, p. 8. 